\title{
Problematic (Post)Sarmatism: On the Possibility of Adapting Sarmatian Heritage in a Demo-liberal Culture
}

The subject of my considerations in this article is (post)Sarmatism understood as a certain conceptual-imagological frame that can be used in reflection on Polish (post)modern civic culture. If the latter is understood more broadly, against the background of its real, historical entanglements in the process of shaping the Polish national habitus, it can be used in reflection on Polish political and cultural identity. Since over the past few centuries, 'the national character of Poles was most often associated with nobility, which was identified with the Sarmatian style, ${ }^{1}$ this reflection cannot be excluded from the Sarmatian theme as long as it aims at far-reaching generalisations. Sarmatism is perceived today by some as

Tomasz Nakoneczny, PhD (ORCID: 0000-0002-4241-7862) - an assistant professor in the Department of Eastern Studies, Faculty of History, University of Adam Mickiewicz in Poznań. He deals with contemporary literary studies and Eastern European identity discourses. Currently, postcolonial research remains his main area of interest. He is the author of the monograph entitled (Po)nowoczesna tożsamość intelektualisty. Wiktor Pielewin i Jerzy Pilch na tle „końca literatury" [The (Post)Modern Identity of an Intellectual: Wiktor Pielewin and Jerzy Pilch against the Backdrop of the 'End of Literature']. Contact: tomasz.nakoneczny@wp.pl.

1 A. Wierzbicki, Spory o polska dusze. Z zagadnień charakterologii narodowej w historiografii polskiej XIX i XX wieku, Warszawa: Muzeum Historii Polski, Collegium Civitas, Wydawnictwo Trio, 2010, p. 11. 
a strictly historical identity formula, intellectually barren in the context of the challenges faced by the postmodern political community, or at best as an imagological matrix providing a certain amount of symbolic capital to popular culture. According to its most ardent deconstructors, Sarmatism remains a formation that exhibits a set of distinctive features fundamentally contrary to the system of values that characterise a contemporary demo-liberal culture, such as exclusivity, racism, xenophobia, paternalism, anti- urbanism and so on. According to its apologists, on the other hand, it is simply 'the essence, foundation or idiom of Polishness,' 2 a fully original heritage, however, obscured by (post)Enlightenment manipulations, without which it is impossible to understand the meanders of modern and postmodern Polish history and the mentality of today's Poles. ${ }^{3}$

This configuration of attitudes is not an unprecedented phenomenon in the Polish identity discourse and is subject to various taxonomies (recently, most often - the postcolonial one ${ }^{4}$ ). Following Jerzy Jedlicki's genealogy of Polish modern thought described in his Jakiej cywilizacji Polacy potrzebuja [What Kind of Civilisation Do Poles Need], we find that the progenitors of today's division into native 'Europeans' and 'anti-Europeans' (to use one of the possible binary oppositions here) are the eighteenth-century spokesmen of the Enlightenment and their Sarmatian adversaries. ${ }^{5}$ The issue can therefore be perceived from a longer and

2 Cf. J. Kowalski, Niezbędnik Sarmaty. Dumy, pieśni, polonezy, poprzedzony Obrona i Uświetnieniem Sarmacji Obojej, Poznań: Fundacja św. Benedykta, 2009.

3 Ibidem.

4 An interesting discourse analysis from this point of view has been presented by Tomasz Zarycki in: Wybrane kategorie analizy dyskursu w badaniu tożsamości peryferyjnej, in: A. Horolets (ed.), Analiza dyskursu i dla socjologii, Toruń: Wydawnictwo Adam Marszałek, 2008.

5 'In Polish thought, the problem of the civilisation option appeared in the middle of the 18th century, and soon became - along with the issue of the reform of the state system - the main topic of the political and cultural debate of the Polish Enlightenment. After all, the struggle of the enlightened with the Sarmatians was about whether the Polish Republic was to become a participant in European progress or to remain on the sidelines of this path, cultivating its own separateness; at the same time, however, within the country's intellectual elite - and in the West - there were deep differences of opinion about the 'Enlightened age' and about the face of the new civilisation.' J. Jedlicki, Jakiej cywilizacji Polacy potrzebuja, Warszawa: Wydawnictwo WAB; Wydawnictwo CiS, 2002, p. 14 (all quotations, except those taken from English-language sources, in this article are my translation). 
broader evolutionary perspective. Moreover, considering the specificity of the Polish road to modernity, the confrontation of the Sarmatians with the enlightened ones can be seen as an ideological issue pivotal for the entire modern and postmodern history of Poland. ${ }^{6}$ The significance of this confrontation stems from the fact that it concerns the attitude towards modernity (or, as Jedlicki puts it, the choice of the 'civilisation option'), the greatest and most multifaceted challenge that was faced by the Polish habitus, largely shaped by Sarmatian culture in modern times.

There are methodological discrepancies regarding the adequacy of the contemporary conceptualisations of Sarmatism in relation to its historical referent, as well as the characteristics of the referent itself. There are also questions about the sense of evoking (post)Sarmatian themes in the context of vital issues in contemporary socio-political life. Here we can see a profound difference between the culturalist approach, which revives Sarmatism for the needs of the contemporary identity discourse and treats it as an integral whole, and historiographic approaches that differentiate its image. The fundamental lack (only partially compensated by Jan Sowa's book, which is discussed later in the article) of holistic approaches,

6 Of course, it is impossible to deny today, particularly after reading Maciej Parkitny's book Nowoczesność oświecenia [The Modern Nature of the Enlightenment] that the traditional image of the conflict between the Enlightenment and Sarmatism is stereotypical. As the Poznan researcher notes in the introduction: 'the image of the Polish Enlightenment initiating modernity, by no means anti-Christian, entering into complex and not necessarily antagonistic relations with its own Sarmatian tradition, reflective and prone to self-criticism - not in all elements, perhaps even in a few, coincides with the traditional image of the epoch preserved in school textbooks and petrified in the collective consciousness.' M. Parkitny, Nowoczesność oświecenia. Studia o literaturze i kulturze polskiej drugiej połowy XVIII wieku, Poznań: Wydawnictwo Naukowe Uniwersytetu Adama Mickiewicza, 2018, p. 12. However, despite the dialectic nature of the historical relationship between the Enlightenment and Sarmatism, we can assume that the image of antagonism between the two formations, created primarily in the nineteenth century, retains symbolic and social importance.

7 'Thus, although the basic elements of Sarmatism were established before the Swedish wars, it was only in the second half of the seventeenth century that it gained the greatest influence among the nobility. From the beginning of the next century, Sarmatism assumed its final, caricatured and - one might say - degenerate forms.' J. Tazbir, 'Sarmatyzm a barok', Kwartalnik Historyczny, 1969, No. 4, p. 819. Cf. S. Baczewski, Szlachectwo. Studium z dziejów idei w piśmiennictwie polskim. Druga połowa XVI wieku - XVII wiek, Lublin: Wydawnictwo Uniwersytetu Marii Curie-Skłodowskiej, 2015. 
integrating various research competences and balancing the influence of various ideological sensitivities, can be more severely felt. ${ }^{8}$

Regardless of the importance we would like to ascribe to the debate on Sarmatism and the individual positions it comprises, we should not forget that in Polish consciousness, Sarmatism remains the only authentically native, historically legitimated school of civic thinking. Its formative, identity-forming role is increased by cultural multidimensionality: elements of customs and elements of everyday life (hospitality, neighbourhood visits, family meetings, feasts, hunting, the characteristic Old Polish split-sleeve overcoat), aesthetics (baroque), architecture and topography (a manor house or a magnate's palace, a village where petty nobility lived, a farm, an inn, a church and so on) are inseparable from political ('golden liberty', republicanism, anti-monarchism), spiritual and intellectual (quietism, traditionalism, anti-rationalism) and religious values (adherence to post-Tridentine Catholicism, rituals, Marian cult). On the other hand, the Sarmatian heritage owes its permanent presence in the social consciousness to the fact that 'literary creativity turned out to be the domain of the Sarmatian tradition," and its phenomenal popularity - to film and the institution of cinema and television popularised in communist Poland. The priority of literature, however, remains unchallenged in this respect because it has provided the basic narrative-symbolic resource. 'Within its [literature - T.N.] scope - observes Aleksander Nawarecki - a fundamental system of myths and stereotypes has crystallised and attempts have been made to question and overcome them. ${ }^{10}$ Therefore,

8 Janusz Tazbir already wrote about the need for integrated, multidisciplinary research on Sarmatism half a century ago. 'Sarmatism requires further research; today, when there is so much talk about the integration of the humanities, it is here that it is particularly needed. From historians of law to historians of literature, everyone should collaborate in the study of this issue.' J. Tazbir, 'Sarmatyzm..,' p. 829. Jan Sowa places Sarmatism in an even broader reflexive and research context, combining the methodology of the Annales School, the world-systems theory and Lacanian psychoanalysis, among others. Cf. J. Sowa, Fantomowe ciało króla. Peryferyjne zmagania z nowoczesną formą, Kraków: Universitas, 2012.

9 A. Nawarecki, Sarmatyzm [entry], in: J. Bachórz, A. Kowalczykowa (eds.), Stownik literatury polskiej XIX wieku, Wrocław - Warszawa - Kraków: Zakład Narodowy im. Ossolińskich, 2002, p. 858.

10 Ibidem. 
not being a political or philosophical doctrine, and even presenting itself as a worldview marked by visible incoherence, Sarmatism has gained an impact on Polish thinking about tradition and on the attitude of Poles to their own political identity, disproportionate to its intellectual importance. From the perspective of the 'long duration' and real socio-cultural dependencies, it would probably be more correct to talk about the Sarmatian habitus, but this issue must remain, due to the length of this article, beyond the scope of these considerations. ${ }^{11}$

Today we deal with three main modes of 'using' this heritage. The first involves searching for the rudiments of the Sarmatian world of values and lifestyle in the contemporary Polish habitus. ${ }^{12}$ The legitimacy of this procedure seems to be determined by the need for compensation, ${ }^{13}$ therefore it is not a coincidence that this mode occurs in the area of right-wing thought and also in postcolonial studies.

11 I deal with an image of Sarmatism as a strictly historical formation, grounded in collective consciousness and maintained by traditional historiography. As a result, 'Old Polish custom' and 'ideology of the nobility' have become the terms that identify Sarmatism most strongly. The term 'Sarmatian culture', used, for example, by Janusz Maciejewski, has also been incorporated into the canon of historians' ideas: 'I treat Sarmatism as a cultural formation, that is, the entirety of human behaviour and its products within a specific society in a specific period of its historical development.' J. Maciejewski, 'Sarmatyzm jako formacja kulturowa: (geneza i główne cechy wyodrębniające), Teksty. Teoria Literatury, Krytyka, Interpretacja, 1974, No. 4, p. 19. Therefore, in contemporary culturalist discourse, it is safer to use the term '(post) Sarmatism', in which the prefix 'post' can be read in both ways: as a signal of continuation and overcoming.

12 The concept of habitus that I use here may be treated by attentive readers of Pierre Bourdieu as a kind of semantic misuse. Since 'different conditions of existence produce different habitus', defined by various skills and competences acquired by an individual, taking the form of very specific ways of perceiving the world, as well as rules of action and thinking, it would probably be more correct to talk about different types of habitus instead of one - Polish or even Sarmatian - habitus. It seems, however, that such striving for historical and sociological precision (we would then have to talk about intellectual, nobility, bourgeois, peasant and other types of habitus) would excessively complicate this argument, which is guided by a synthetic goal. Cf. P. Bourdieu, Distinction: A Social Critique of the Judgement of Taste, Cambridge, MA: Harvard University Press, 1984, p. 170.

13 The concept of compensation has many references in both social sciences and the humanities. Here it refers to the psychosocial dimension of experiencing modernity, which is close to what Francis Fukuyama describes in terms of thymos. Cf. F. Fukuyama, The End of History and the Last Man, New York: The Free Press, 1992. 
The second mode involves functionalising Sarmatism as a construct with a changing purpose, usually determined by short-term political goals or by a trend whose origins are always more difficult to grasp. This mode appeared as part of the cultural policy of the People's Republic of Poland (although there are reasons to look for a strong compensatory motivation in the communist evocations of Sarmatism). It is shown in a spectacular form in the large-scale film adaptations of Henryk Sienkiewicz's historical novels and in large editions of works by authors dealing with Old Polish themes. Today, however, Sarmatism makes itself felt due to various both mass and niche - forms of promotion and entertainment in a broad sense, such as: advertising campaigns (for example, 'Warka' beer), product brands ('Husaria' [Polish hussars] vodka ${ }^{14}$ ); media forms popularising Old Polish cuisine; the popular song 'Do boju Polsko' [Stand up and fight, Poland] referring, in its different variants, to the knightly ethos of the First Polish Republic; fantasy literature (for example, the best-known example of Old Polish threads in Andrzej Sapkowski's 'Witcher' cycle); and games referring to Sarmatian imagology (board, computer, card, field and other games), about which Michał Mochocki writes interestingly in his article entitled Sarmackie dziedzictwo kulturowe w grze fabularnej Dzikie Pola [Sarmatian Cultural Heritage in the Role-playing Game 'Wild Fields']. ${ }^{15}$ This group also includes the effective literary representation of Sarmatism in the works of Jacek Komuda, Maciej Lizniewicz, Jacek Piekara and Andrzej Ziemiański. Actually, the entire stream of Polish literary fantasy

14 In the description of the brand's semantics, there is an interesting attempt to link the business axiology (professionalism, reliability, partnership) with the fraternal, communal Sarmatian ethos. 'Members of the Polish hussars were elite: brought up in the ethos of knightly bravery, they recruited from wealthy nobility, and service in this formation was considered a great honour. Hussars were characterised not only by perfect mastery of battlefield craftsmanship, but also by equipment, which consisted of precise, refined in the smallest details, original weapons. Hussars were like brothers and could count on each other at any time, which was also their strength. The same values that can be used to describe the most eminent units of the Polish cavalry also characterise the new vodka in the portfolio of CEDC [Central European Distribution Corporation - an American joint-stock company, the largest vodka producer in the world]', https://www.portalspozywczy.pl/alkohole-uzywki/wiadomosci/cedc-wkracza-narynek-z-nowa-wodka-z-segmentu-premium,153724.html (accessed: November 2020).

15 Cf. M. Mochocki, 'Sarmackie dziedzictwo kulturowe w grze fabularnej Dzikie Pola', Homo Ludens, 2011, No. 1/3. 
reviving the Sarmatian ethos in the spirit of right-wing values reveals its compensatory feature, which is perhaps most visible in the nostalgia for the retro-utopian ideal of familiarity, authenticity and colourfulness. ${ }^{16}$

As a result, the division into the three modes of perception of Polish noble culture used here should be considered as quite conventional: the second mode can be largely included in the first one. Its separation is justified by its discursive heterogeneity manifested in various levels of expression: linguistic, narrative-symbolic, ideological, moral and so on, distinguishing it from a more homogeneous, openly ideologised, critical-argumentative line of considerations defining Sarmatism as a definite and generally positive paradigm of Polishness, whose main - though not always articulated - advantage seems to be its ability to fill in gaps and eliminate contradictions or discontinuities in the Polish system of self-presentation. By extending this point of view to all the lessons of the historical Sarmatian formation, standardising its image and making it consistent (explicitly or implicitly), we could come to the seemingly paradoxical question of whether the aforementioned trend should also include many strictly historical narratives by excellent academic researchers, such as Maria Bogucka, Janusz Maciejewski, Jarema Maciszewski, Janusz Pelc, Janusz Tazbir and Tadeusz Ulewicz (to name only a few). Jakub Niedźwiedź's publication entitled Sarmatyzm, czyli tradycja wynaleziona [Sarmatism, or an Invented Tradition] indirectly encourages this kind of nonconformist revision of the position of Sarmatism in the epistemological plane. As the author rightly

16 An example illustrating the way in which reality is modelled by the neo-Sarmatian literary discourse can be the following fragment of Jacek Komuda's prose: 'If Mr Dydyński had stepped into an inn in distant France or the Netherlands, he would have been surrounded by the mournful and pale faces of Germans sipping fine wine from goblets. Title-holding townspeople and cowardly bachelors hiding their faces under their wigs. Cool and refined people, speaking through their teeth and making sure that, God forbid, not a drop be wasted from the chalice, or that they not fall under the table in a drunken dream. Fortunately, it was an inn in the Commonwealth, so Mr Jacek was surrounded by the red mouths and coarse faces of the Polish nobility, and his ears were struck by the singing and screams of drunken brethren. He could see their gobs marked with bumps, scars from sabre cuts and gunpowder. Ruddy and pale gobs, decorated with noses red from drunkenness. Fawn and black shaved hair, bushy moustaches - sometimes uneven, because cut by a neighbour or a competitor for a girl. Honest and open, drunk and cheerful but, above all, sincere and coarse faces.' J. Komuda, 'Nobile verbum', Nowa Fantastyka, 2003, No. 8, p. 14. 
points out, the key notions, constitutive of the meta-Sarmatian construct, such as the ethnogenetic myth or the topos of Bulwark, were not only characteristic of Sarmatism (the Lithuanian and Ruthenian projects were competing in this respect) or of the First Polish Republic (the conviction about the borderline nature of their cultures was strongly marked in the consciousness of the Hungarian, Transylvanian and Moscow elites). This creates a natural need to verify theses about its paradigmatic nature. 'If - notes Jakub Niedźwiedź - we take a closer look at the rhetoric used to describe Sarmatism and refer to sources outside the 'Sarmatian' canon of texts, it turns out that we do not have a coherent image of Sarmatism, but a patchwork with clearly visible seams. As a result, we will come to the conclusion that the nineteenth and twentieth-century narratives whose authors undertook to describe the referent of the concept of Sarmatism are unconvincing. ${ }^{\prime 7}$ The involuntarily compensatory (Polonocentric) nature of the objectivising views makes us realise the special, specific importance of the cultural component not only in historiographic but also in all evocations of Sarmatism. Our ambiguous taxonomy can thus be treated a little less strictly. I point to these issues here primarily in order to confirm the problematic nature of Sarmatism, indicated in the title of this article, and postpone its possible further development for another time, in another text.

Finally, the third mode of dealing with the Sarmatian legacy occurs in the liberal discourse, generally unfavourable to Sarmatism and aimed at discrediting any attempts to revive it. While the enthusiasm of seekers of Sarmatism is motivated, at least in part, by their cultural essentialism, the reluctance and scepticism of its deconstructors results, to a comparable degree, from their belief in a fundamental contradiction between the Sarmatian worldview and liberal values. The dispute over Sarmatian heritage still bears, like in the Enlightenment that started it, the features of a cultural dispute and sheds light on the broader, pan-European/ civilisation-related entanglements of the Polish identity discourse.

Both basic lessons of Sarmatism - the conservative-right-wing and demo-liberal - lead to simplifications that are difficult for a historian to 
accept, but justified and even necessary in the symbolic-narrative agon. The common denominator of both is anachronism: while conservative apologists of Sarmatism are too hastily satisfied with recognising its selectively treated advantages (sociability, moral autonomy, high self-esteem and so on), liberal critics make its ideological and moral recontextualisation (corresponding, of course, to contemporary standards) ${ }^{18}$ thereby moving away - sometimes very carelessly - from historical realities. I believe that it is possible to partially reconcile both orientations and thus 'salvage' certain aspects of the Sarmatian ethos without giving up both a critical view and attachment to the source orthodoxy.

The necessary condition would, however, be a consensual loosening of the perceptual rigours linking Polish identity projects with essentialistically understood Polishness, and in the optimal variant - recognising the claims of demo-liberal culture to the general de-metaphysication/disenchantment of tradition and granting it the status of a symbolic-narrative residue from which this culture could derive a useful content for itself. Useful, that is, in line with the standards of contemporary civil societies: open, tolerant, and in the sphere of public life institutions - deliberative and pluralistic.

In this respect, Sarmatism appears to be a text of culture, in many ways attractive, because it is a tradition not overburdened by intellectual ambitions (and thus susceptible to various extrapolations and inconsistencies), devoid of historical continuity, and - in the present reality - a social medium (which makes it ethically non-binding and 'indifferent' in class terms). Moreover, its programme layer contains functional components within the demo-liberal order, such as civic participation, political pluralism, ahistoricality, syncretism and so on. The problem is that, due to the merging of Sarmatism with the category of essentialistically understood Polishness, it has been almost completely

18 One type of the anachronism in question is also pointed out by Tomasz Zarycki in his review of Jan Sowa's book entitled Fantomowe ciato króla [The King's Phantom Body]. This type involves a specific essentialisation of the object and evaluation criteria. It is for this reason that the reviewer accuses the author of applying the measure of contemporary ideals of 'civic, open, multicultural society' when describing the heritage of the First Polish Republic. See: 'Recenzja książki Jana Sowy, Fantomowe ciało króla. Peryferyjne zmagania z nowoczesną formą, Stan Rzeczy, 2012, No. 1, pp. 222-230. 
appropriated by the conservative-right-wing discourse, and all possible attempts to dismantle this relationship seem doomed to failure.

Perhaps the stake in saving (post)Sarmatism is, in the first place, its suggestive and well-established presence in popular culture. Therefore, it is important for it to find conditions to reveal its potential for contingency and hypertextuality, ${ }^{19}$ which today determine the degree of the text's ability to be present in other spaces of culture. Therefore, the best that could happen to it today would be to experience another wave of fictionalisation, following at least three others in its 'post-mortem' history, the romantic one (Seweryn Goszczyński, Adam Mickiewicz, Juliusz Słowacki, Henryk Rzewuski), the romantic-positivist one (Teodor Tomasz Jeż, Józef Ignacy Kraszewski, Walery Łoziński, Henryk Sienkiewicz) and the communist one. The academic discourse can only play a minor role here, describing certain states of affairs or inspiring re-evaluation in the sphere of thinking about them. Today, the vitality of a given cultural content (and thus its potentially identity-forming rank) is determined primarily by its ability to penetrate popular culture and become rooted in it. Of course, there is still a lot of room for action in the field of institutionalised historical policy, but I mention this in the last part of my considerations.

Although the postulate of de-essentialisation to enable the 'adaptation' of Sarmatism by liberal culture seems to fit in medias res of domestic ideological disputes centred around the dichotomy of Polishness and Europeanness, tradition and modernity, and so on, there are some general reasons behind this. It should be noted, however, that it is not about de-essentialisation of (post)Sarmatism itself, but about a departure from the identity code that automatically registers phenomena of the past in centric categories: ethnocentrism, male-centredness, monolingualism, and so on. ${ }^{20}$ (Post)Sarmatism itself appears today as completely de-essentialised

19 Here, hypertextuality means the possibility of treating (post)Sarmatism as a multifunctional and multidimensional text of culture, which can be assimilated on various axiological or aesthetic levels and read using various interpretative codes.

20 The identity monoperspectivity that characterises Polish thinking about the past is interestingly illuminated by Bogusław Bakuła in the context of the Polish borderland discourse. 'I would distinguish "borderlands", the researcher writes, 'as a form of Polish ideologisation of the past and the Borderlands as a multicultural, equal form of coexistence of nations on the territory of the former First Polish Republic, and then at the meeting point of states, nations, mixed up 
in its political and state dimension, while in the ideological and aesthetic dimension it has been so from the very beginning due to its syncretism (irreducibility to any component - doctrinal, moral or aesthetic).

Let us return, however, to the above-mentioned general reasons. First of all, it is worth paying attention to the fact that the aforementioned dichotomies can be put in the context of general civilisation, which is often done within the framework of various sociological or cultural approaches. However, this does not always lead to clarification of specific issues, such as the sources of the legitimacy of tradition in the conditions of (post) modern society. This context is perhaps best illustrated by the reference to the turning point set by the Great French Revolution in meta-community thinking. At that time, the ideological disputes between the followers of various kinds of traditionalism and progress - so far embedded in specific discursive areas, such as philosophy, morality or aesthetics - merged into one fundamental discourse, based on their attitude to the Revolution and ancien régime. Sarmatism is clearly located here on the side of tradition, disavowed in various ways by the ideological progenitor of the Revolution. It is precisely this positioning of the Sarmatian - or more precisely: post-Sarmatian - thread that gives rise to the question of how Sarmatism functions as a tradition, and thus as a semantically more capacious (and at the same time incomparably less defined) category than a cultural artefact, myth or ideology. It seems that it is in this monumental role that it exists, rather potentially, in modern and postmodern discourses. All its recontextualisations made since the Enlightenment take place on a relatively narrow mythic or - to an even more limited extent ideological plane. Only the contemporary neo-Sarmatian discourse and postcolonial studies evoke the possibility of treating Sarmatism as a component or synonym of Tradition. Tradition, the significance of which would result from the combination of several seemingly mutually exclusive steps: (a) essentialisation (identification not with the narrow,

in the nineteenth century and the first half of the twentieth century.' B. Bakuła, 'Kolonialne i postkolonialne aspekty polskiego dyskursu kresoznawczego (zarys problematyki)', Teksty Drugie, 2006, No. 6, p. 23. This kind of monoperspectivity results in the preservation of the habit of essentialising individual components of the community habitus, including the 'national character', sources of origin, etc. 
ethnocentric Polishness avant la lettre, but with Polishness understood broadly, inclusively, civically); (b) dialectisation (opposition to modernity, the symbolic instauratory moment of which is the French Revolution); and (c) functional textualisation (the liquidation of ties with the socio-historical genealogy of Sarmatism in favour of a periodically updated depending on cultural or political trends - image of tradition).

Essentialisation seems to be an inherent attribute of all thinking in terms of tradition and traditionalism: without the projection of its irreducible, immanent values, understood per se and treated as natural, tradition descends to the level of convention and thus ceases to be a tout court tradition. The belief, the assumption or at least the suspicion that a given tradition belongs to the order - according to Max Scheler's terminology of a (relatively or absolutely) natural worldviews appears as a sine qua non condition for any culturally motivated strategy of dealing with it. As long as there are impulses within a given cultural and historical community that encourage the reinterpretation of the world-outlook content present in it as 'living' or 'authentic' elements of a specific tradition, ${ }^{21}$ this tradition will remain a potentially important reference for all attempts at the self-definition of this community. Moreover, the postulate of its essentiality (meaning at least its irreducibility to specific modalities - social or other, latent reproducibility in the process of inheriting cultural memory) should also be impossible to ignore.

Another component of our characteristics, the juxtaposition of tradition and modernity, anchors the Sarmatian discourse in History; here history is understood no longer - not primarily - as an empirical system of events, but as a metonymy of a specific civilisation and cultural process (hence the use of the capital letter is legitimate), oriented, essentially rational and fulfilling certain values (freedom, equality or emancipation). It is therefore about the historical finalism, which is represented spectacularly in contemporary liberal culture by Fukuyama's

21 "The "authentic" content of tradition is only the content that is experienced visually as current and is therefore neither known to its carrier nor realised by them as tradition.' M. Scheler, Teoria światopoglądów, socjologia $i$ kształtowanie światopoglądu, in: idem, Pisma zantropologii filozoficznej $i$ teorii wiedzy, trans. S. Czerniak, A. Węgrzecki, Warszawa: Państwowe Wydawnictwo Naukowe, 1987, p. 389. 
concept of the 'end of history', from the perspective of which the demo-liberal system meets the conditions of a realistically understood utopia: an ideological construction within which the struggle to create a better in an ideological and political sense - society loses its sense.

This brings us to the most important point of this part of our discussion. Both evoked forms of utopism - retrospective (traditionalist) and progressivist (finalistic) - enter into a dialectical interaction based on the construct of postmodernity. As Gianni Vattimo aptly points out, 'the most characteristic - and perhaps the most widely considered - feature of postmodernity is seeing it as the end of history.' ${ }^{22}$ In the context of the 'end of history' as an alternative to the irrational, entropic trajectories of history, both of the aforementioned utopisms, founded on their respective hypostases of order, in fact turn out to be different strategies of 'coping' with modernity. Thus, they ultimately come closer to one another. They are fundamentally differentiated by the identification of the basic order-forming factor: in the case of the demo-liberal utopia, it is reason (the belief in the uniformity, universality and rationality of human nature), and in the case of the retrospective utopia - the belief in the past (the belief in the natural superiority and benevolence of the 'previously established' order).

How is it possible that tradition has evolved into thisspecific counterpart of the demo-liberal order? This happened thanks to the transformation of tradition from a 'treasury of souvenirs' into a world-outlook substrate shaped under the conditions of a unique cultural transformation. Due to the violation of the relatively uniform, pre-modern order by the forces of the Revolution, Tradition placed itself automatically and irrevocably on the side of the past. Having lost the status of the 'eternal', self-evident order of things, it has become temporal (subjected to historicisation and relativisation), contested and, at the same time, contesting, a pendant of the modern world. Due to the scale of the aforementioned violation, the determination of oneself in relation to Tradition acquired the features of a clearly worldview-forming act. The latter circumstance is of additional importance in the light of the fact that, as Anthony Giddens observes, in

22 G. Vattimo, Postnowoczesność i kres historii, trans. B. Stelmaszczyk, in: R. Nycz (ed.), Postmodernizm. Antologia przekładów, Kraków: Wydawnictwo Baran i Suszczyński, 1996, p. 128. 
a 'post-traditional social order', traditions 'have to explain themselves. ${ }^{23}$ Thus - in terms of social pragmatics - their advocates must find/renew arguments supporting their essentiality or praxeological utility.

Situating Sarmatism in the context of tradition understood in this way, and not - as is generally done - in the narrow perspective of a historical myth, an aesthetic imaginary or a collection of mental and moral rudiments, may seem at first glance an intellectual extravagance. However, the situation will change if we look at the attempts to 'sarmatise' Polish identity undertaken in the twentieth and twenty-first centuries. This can be seen as the way to fill the gap which, in the social/civic dimension of community thinking, was caused by the dismantling (partitions) of civic and state culture. The question of whether Sarmatism is a latent feature of Polish thinking - as it is usually presented by right-wing authors such as Rafał Ziemkiewicz ${ }^{24}$ - or deserves the name of an invented tradition today seems to be less important than the fact that, due to its archaic, discontinuous and syncretic nature, it potentially lends itself to being 'tamed' by a liberal culture.

However, there are several obstacles on this path. One has already been mentioned: it is the deeply internalised habit of including Sarmatism into essentialistically understood Polishness. Due to this, liberals ignore the possibility of recognising in Sarmatism the fundamental frame of reference for reflection on Polish civic culture at the level of meta-Sarmatian discourse; in this optics it still represents a peculiar, sometimes

23 A. Giddens, Beyond Left and Right: The Future of Radical Politics, Cambridge: Polity Press, 1994, p. 5.

24 Ziemkiewicz considers Romanticism to be the essence of Polishness, yet he admits at the same time that it played the role of a vehicle in Polish culture transferring some Sarmatian values hidden in new forms of expression to modernity. R. Ziemkiewicz, 'Resztki Oświecenia,' Uważam rze, 2012, No. 2, available at: http://www.old.uwazamrze.pl/artykul/805027/resztkioswiecenia (accessed: November 2020). Andrzej Leder speaks more openly and unequivocally about the genetic ties between Romanticism and Sarmatism: 'It must be remembered that the romantic universe grew out of the nobility's imagery, this particular cultural formation established by the First Polish Republic in the vast territories between the Baltic and Black Seas. Pan Tadeusz by Mickiewicz, the "platform" transferring the Sarmatian imagination to the area of the nineteenth century, is the most important testimony of the relationship between Romanticism and the tradition of a noble farm.' A. Leder, Prześniona rewolucja. Ćwiczenie z logiki historycznej, Warszawa: Wydawnictwo Krytyki Politycznej, 2014, sp. 16. 
even troubling, heritage. And this should not be the case if we consider the extremely contingent dimension of the Sarmatian tradition, which is characterised by the already stressed discontinuity, local character and singularity. The experience of contingency seems to be inscribed in the Polish history of the last three hundred years. When Dariusz Gawin writes about the 'ontological clearance' - meaning the real and permanent, under the conditions of the Polish situation, possibility of losing the national existence ('Poland exists, but it may cease to exist') - he draws attention to a key aspect of this experience. ${ }^{25}$

It can be assumed that this trait of the contingency of Polish history has not been fully appreciated by liberal thought, which usually points to the native maladjustment and secondary nature in relation to the modern world and does not factually examine the unique Polish entanglement in the dialectical conjunctions of modernity and traditionalism. Let us, however, go back to Sarmatism. This tradition - which is genealogically connected with the First Polish Republic, marks the unique Polish road to modernity with the memory of the past glory and, at the same time, hides deep social conflicts under the democratic staffage ${ }^{26}-$ should be treated $^{2}$

25 'In Polish identity, therefore, there has been a tacitly accepted assumption for over two hundred years that a permanent element of our situation, our fate, is the totality of historical, geopolitical and cultural circumstances, which can be described as an 'ontological clearance'. The point is that Poland exists, but it may not exist, that it may "perish", cease to exist. Apparently, this seems like an exaggeration. However, when we take a closer look at the history of the nation in the period that began with the Slaughter of Praga [district of Warsaw] and found its culmination in Katyn and the Warsaw Uprising one hundred and fifty years later, one cannot help but feel that this was the leitmotif of most of the history of the nineteenth and twentieth centuries.' D. Gawin, Przekleństwo 1709 roku. Czy Polacy moga wybić się na podmiotowość?, http:// www.omp.org.pl/stareomp/index $2498 . h$ tml module $=$ subjects\&func $=$ viewpage\&pageid $=772$ (accessed: November 2020).

26 'The political doctrine of Sarmatism bears clear features of a class ideology, and the same ideology may mask or exacerbate significant social conflicts. Sarmatism fulfilled both of these roles: it weakened the antagonism of the nobility and magnates, and exacerbated the conflict of the gentry with townspeople and peasants. In developing the Sarmatian myth, the separate position of the nobility is strongly emphasised. Only the nobility was said to descend from the Sarmatians; plebeians, both townspeople and peasants, had a completely different lineage.' J. Tazbir, 'Sarmatyzm..., p. 821. The image of social conflicts within the noble state is even more dramatic in Jan Sowa's work. He writes, inter alia, about the introduction of 'a heterogeneity barrier between the nobility and the rest of the residents of the Republic of Poland' J. Sowa, Fantomowe ciato..., p. 262. 
with much greater seriousness and insight by liberal thought. Namely, its habitus - hybrid, full of nuances, understatements, inconsistencies and even outright contradictions - simply fits better with the liberal cultural horizon than the conservative one. One can even risk the statement that Sarmatism could owe the making of its status of tradition more realistic to a critical and nuanced demystification rather than to conservative apologetics; conservative interpretation condemns it to the status of a historical myth at best.

It would be difficult to understand the reluctance of the liberal discourse towards Sarmatism without considering the psychological consequences of the confrontation of tradition with modernity. For the supporters of an open, modern, civic and tolerant Poland, which continues the Enlightenment tradition of 'throwing off the yoke' of the 'idols of Sarmatism', making the Polish nation 'the laughingstock of scholars,', neo-Sarmatian sentiments and the retro-utopias revived by them belong, at best, to the sphere of amusing folklore. In the worst of all, they are perceived as a manifestation of the wrong - as in two hundred and three hundred years ago - response to the challenges of the modern world. The strong rooting of the orientalised image of Sarmatism - as an exotic and mysterious as well as dangerous and destructive phenomenon - can be evidenced by a statement from a review of a contemporary art exhibition inspired by Polish Baroque art: 'The exhibition lacks exaggeration. After all, we are talking about Sarmatians, not sweet little dogs. A phantasm that can still be thoroughly dangerous and harmful. If we want to transgress and rework it, we must radically deconstruct it. ${ }^{28}$

The author of this review, Katarzyna Oczkowska, seems to forget here that the radical deconstruction of Sarmatism has already been present in

27 Monitor Warszawski, 1765, No. 30, pp. 234-235, https://www.dbc.wroc.pl/dlibra/publication/4638/edition/4474/content (accessed: November 2020).

28 K. Oczkowska, Popsarmackość. Wielcy sarmaci tego kraju / Wielkie sarmatki tego kraju w BWA Tarnów, https://magazynszum.pl/popsarmackosc-wielcy-sarmaci-tego-kraju-wielkie-sarmatkitego-kraju-w-bwa-tarnow/ (accessed: November 2020). 
the Polish identity discourse (enough to mention the already emblematic deconstructors of the Sarmatian style of thinking, such as Ignacy Krasicki, Stanisław Brzozowski and Witold Gombrowicz). It seems that a better idea today to 'transgress' and 'rework' the Sarmatian phantasm would be to deconstruct its stereotype and focus attention on the reasons for its vitality. These, in turn, are probably best explained by the notions of lack (deficit) and nostalgia: after all, Sarmatism appears in its positive evocations, so eagerly deconstructed by native advocates of modernity, as an expression of neo-imperial (superpower) sentiments, the need for community consolidation and finally - especially in its reflective, neo-Sarmatian variant described by Paweł Bohuszewicz - as a construct used to overcome modernity. ${ }^{29}$

When describing the Polish state-national tradition in terms of lack and loss (of sovereignty, citizenship, subjectivity, proper development of the conditions of modernity, and so on), one must be aware that its spiritual correlate is the need for compensation. The role of the compensation mechanism in modern culture has been thoroughly described by Odo Marquard. In his description, the idea of compensation takes - as Anna Zeidler-Janiszewska succinctly puts it - the form of an 'all-encompassing' concept of modern culture as compensation for modernising deficits. ${ }^{30}$

The German philosopher's comprehensive application of the category of compensation encourages its use to explore Polish 'modernising deficits', which must appear obvious in the light of the delayed start to modernity and, primarily, the multiple externalised (in both artistic culture and everyday attitudes) deprivation of the need for dignity caused by the national disasters of the last three centuries. Przemysław Czapliński, among others, draws attention to the compensatory nature of references to Sarmatism in the communist period. 'A modern Pole - notes the literary scholar - needed a genealogy that would ennoble and not restrict

29 Cf. P. Bohuszewicz, Pożytki z prawicowego neosarmatyzmu. (Nie-prawicowa) obrona Krzysztofa Koehlera, in: P. Biliński (ed.), Przeszłość we wspótczesnej narracji kulturowej. Studia i szkice kulturoznawcze, vol. 1, Kraków: Wydawnictwo Uniwersytetu Jagiellońskiego, 2011.

30 A. Zeidler-Janiszewska, O pożytkach politycznego kaskaderstwa. Szkic do portretu Odo Marquarda, in: O. Marquard, Rozstanie z filozofia pierwszych zasad, trans. K. Krzemieniowa, Warszawa: Oficyna Naukowa, 1994, p. 11. 
movements. Communist Poland was unable to create anything like that, so many people sought to be rooted in the noble tradition..$^{31}$ Elsewhere, the researcher writes about Sarmatism, revitalised since the 1960s due to cultural policy, as giving 'an undisturbed sense of pride in belonging to a community'. The reactions of the first reviewers of Jerzy Hoffman's film 'The Deluge' are significant in this context. Krzysztof Teodor Toeplitz wrote that 'our audience has seen in "The Deluge" an image that in some way compensates for the need for national success.32 On this occasion, Aleksander Ledóchowski attempted to reflect more generally on Sienkiewicz's, paradigmatically neo-Sarmatian, image of a Pole: 'Perhaps it is him [Henryk Sienkiewicz - T.N.] who was able to say what we were and what we are and will be. He created our spiritual portrait with all its advantages and disadvantages, a beautiful and picturesque portrait. By showing us as we were in the past, he showed us as we are in contemporary times. And, most importantly, his art is psychological compensation for contemporary creativity because it shows a Pole as a man of action and a man of the future. ${ }^{33}$ Finally, according to Krzysztof Mętrak, Sienkiewicz's protagonists 'live in us like mythological creatures, expressing national, collective experiences.34 This kind of comment, referring to the way of experiencing the national identity that is considered commonplace (moreover, often associated with the Sarmatian habitus), shows the consistently persistent need for a peculiarly archaic (because it is based mainly on intuitive or emotive premises) confrontation with one's own heritage.

The need to consolidate the sense of community and being rooted in modernity can be considered the main sources of Polish compensatory practices in the communist period. The reluctance towards modernity

31 Gdyby sarmatyzm nie istniał, Michaśka sama by go wymyślita, Jakub Majmurek's interview with Przemysław Czapliński, https://krytykapolityczna.pl/kultura/historia/czaplinski-gdybysarmatyzm-nie-istnial-michaska-sama-by-go-wymyslila/ (accessed: November 2020).

32 K.T. Toeplitz, 'Potop, czyli o rzetelności', Miesięcznik Literacki, 1974, No. 11, p. 89.

33 A. Ledóchowski, 'Potop Jerzego Hoffmana', Kino, 1974, No. 2, p. 9, available at: http://www. archiwum.kino.org.pl/pdf/1974/kino_1974_02_011.pdf (accessed: January 2020).

34 K. Mętrak, 'Potop zwycięski', Kultura, 1974, No. 36. As quoted in: B. Szleszyński, M. Rudkowska (eds.), Sienkiewicz ponowoczesny, Warszawa: Instytut Badań Literackich PAN, 2019, p. 298 [available at: http://nplp.pl/wp-content/uploads/2015/05/Sienkiewicz_Ponowoczesny. pdf (accessed: November 2020)]. 
observed in neo-Sarmatism (which is pointed out by Bohuszewicz) and the simultaneous desire to satisfy the need for recognition through citizenship in the structures of this modernity (which, in turn, Czapliński emphasises) should be treated as an inconsistency suggesting the existence of an unworked (on a collective scale) attitude to modernisation. The interest in Sarmatism as a living element of the collective identity of contemporary Poles, which has also been visible since 1989, gives rise to the need for a more thorough verification of the perception model that stands behind this. Paradoxically, however, the aforementioned archaic way of experiencing community experiences, which does not conform to the norms of rationality promoted by modernity, turns out to be potentially attractive under the programmatically anti-rationalist postmodern culture. (Post)Sarmatism, a typically Polish construct of retro-utopia, with its eclectic idiomaticity, ${ }^{35}$ also idealised today, signals adaptive ineffectiveness, surprising at first glance, in relation to postmodernity (the previously noticed presentations in popular culture are incidental or niche). Here, too, as in the times of the People's Republic of Poland, the inability/aversion to 'play with Sarmatism' deprived of seriousness due to its historical heritage, as well as the lack of respect for the culture-forming aspects of (post)Sarmatism (seen through the prism of the category of lack and compensation, and more broadly through the prism of the location of Sarmatism on the dialectical map of links between tradition and modernity), seems to result from an unworked attitude towards modernity. And going deeper to social sources - from the incomplete assimilation of this modernity.

As a result, we deal with a far-reaching functionalisation of the Sarmatian text and its absorption by mass culture, simplified to the limits of trivialisation. This is clear evidence of the failed attempts to give it the role of tradition. On the other hand, however, we can see attempts/

35 'So, Sarmatism is an idiom that breaks the simple East-West divide. And this is perhaps its greatest value. At that time, we had the remarkable ability to absorb various, often opposing, elements from the most distant parts of the world - from Paris to Afghanistan and Mount Ararat - in such a way that they formed an original and endemic whole here.' M.A. Urbańska, Pochwała sarmatyzmu, https://www.tygodnikpowszechny.pl/pochwala-sarmatyzmu-145412 (accessed: November 2020). 
postulates of its essentialisation (for example, Ewa Thompson, Krzysztof Koehler or Jacek Kowalski), ${ }^{36}$ which prove the need to actually face the possibility of seeing it in this role. However, it will be impossible without including the still not fully explained participation of Sarmatism in the Polish struggle with modernity in its cultural biography.

However, despite its cultural dysfunctionalities, (post)Sarmatism exhibits, as described by Czapliński, the ability to produce political meanings and to activate the layers of collective imagination that allow for the transformation of these meanings into targeted forms of action (the Solidarity movement ${ }^{37}$ ). Focusing his attention on the currently dominant mass/plebeian variant of the Sarmatian stereotype, this researcher considers it to be an 'empty form', possible to fill with new content, depending on the current needs and social interests - 'plebeian' (mass culture) or political (the sphere of power-society relations). The empty frame/form metaphor is defended on a sociological level: without a specific, historically and culturally established social base, Sarmatism remains by necessity - and at best - a kind of frozen symbolic-narrative asset of disputed utility.

Thus, are there any premises for the adoption of Sarmatism in a demo-liberal culture (functional textualisation) while meeting the

36 Paweł Bohuszewicz divides the contemporary - as he calls it - 'neo-Sarmatian hermeneutics' into three types: right-wing, postcolonial and anarchist. P. Bohuszewicz, Pożytki... Cf. also idem, Hermeneutyki sarmatyzmu, in: M. Lutomierski (ed.), Tradycje szlacheckie we wspótczesnej kulturze polskiej. Przyblizenia $i$ perspektywy badawcze, Toruń: Polskie Towarzystwo Ludoznawcze, Oddział w Toruniu, 2014.

37 'The re-semantisation of the Sarmatian stereotype took place at the time when the Solidarity movement was born. Almost all analyses of this movement emphasise its hybrid cultural characteristics: Solidarity was democratic, modelled on workers' rallies and nobles' regional councils, sensitive to political inequalities, and at the same time male-centred, misogynistic and permeated with a powerful Marian cult, ready to change the entire sphere of politics and at the same time based on negation of politics, progressive in the demand for justice and traditionalist, subversive and conservative. Solidarity - choosing freedom, equality and dignity from tradition - established an alliance of modernity and Sarmatism.' P. Czapliński, 'Plebejski, populistyczny, posthistoryczny. Formy polityczności sarmatyzmu masowego', Teksty Drugie, 2015, No. 1, pp. 27-28. 
other conditions for making it a real component or a synonym of tradition (essentialisation, dialectisation)? In other words - is it possible to enchant (post)Sarmatism in a disenchanted time without giving up the critical view of its complicated history? The very discussion around (post)Sarmatism can be treated as a symptom of the re-evaluation taking place in the broad sphere of cultural identity. More generally, it can be described in categories - formulated by Yuri Lotman - of the laws of dynamics of sign systems, usually heralding 'an increase in the pace of cultural development. ${ }^{38}$ However, sign intensification does not guarantee the emergence of a specific type of content or attitude.

I believe that there are potentially at least two ways to make (post) Sarmatism 'real'. One of them is the consolidation of Polish civic culture combined with a real strengthening of institutions and the authority of the state. The other one is the recreation/externalisation of specific geopolitical relationships in Central and Eastern Europe, making its regional identity real and explaining its civilisation and cultural specificity in terms of its long duration, in which perspective the Polish factor would show, as in the times of the Polish-Lithuanian Commonwealth, its above-average integrating and culture-forming abilities. ${ }^{39}$ Since the former could not take place in a symbolic vacuum, it would require more thoughtful forms of

38 J. Łotman, 'Dwa teksty semiologiczne. O pojęciu przestrzeni geograficznej w średniowiecznych tekstach staroruskich', trans. M.R. Mayenowa, Teksty. Teoria Literatury, Krytyka, Interpretacja, 1974, No. 3, p. 110.

39 The geopolitical thread automatically evokes the imperial, hegemonic context in contemporary discourse. 'The thing is that Poles can feel heirs of the empire only in Eastern Europe, where Polish culture used to dominate, set trends and determine a higher level of civilisation. In other words, it was more attractive. Eastern Europe is the only region of the world where a Polish passport, particularly now, when it is also an EU passport, is still impressive, and its owner is considered a visitor from a better world.' A. Brzeziecki, Imperialne złudzenia Polski, https://www.reddit.com/r/Polska/comments/6cnj0j/imperialne_z\%C5\%82udzenia_polski/ (accessed: November 2020). It seems, however, that adopting this perspective in the debate on (post)Sarmatism would unnecessarily narrow the issue. Though the matter remains debatable. For example, Hieronim Grala ('Kolonializm alla polacca', Polski Przeglad Dyplomatyczny, 2017, No. 4) perceives Sarmatism as a political and cultural formation with features of a colonial project. At the same time, it cannot be denied that Sarmatism reflected the real, social, political and civilisational diversity of this region of Europe, integrating it on many levels in the face of contemporary challenges (capitalism emerging in the West, the threat from Moscow, Turkish imperialism, etc.). 
textual canonisation (including revision, not necessarily revolutionary, of the school reading canon and some other elements of the curriculum, as well as a departure from the emotive, incoherent and reactive politics of memory). Particular emphasis should be put on the need to distinguish a field corresponding to the place occupied by their founding myths in modern liberal communities. In his book Granice demokracji liberalnej [Limits of Liberal Democracy], Dariusz Gawin aptly reconstructs the basic cultural dilemmas of liberal modern states. The tension that characterised them between the republican spirit of 'passionate patriotism, which searched for patterns in stories about the power of civil virtues in republican Rome' (characteristic, let us add, of early Sarmatism) and the liberal theory of social contract as the foundation of the political order ${ }^{40}$ was overcome in favour of the latter. 'However, even in the case of liberal thought,' Gawin notes, 'sooner or later the question must have arisen as to where the new type of society was to find the source of its cultural identity capable of uniting its members into something more than just a group of people focused primarily on self-interest."1 This is where the 'search for the glue for the political body in the founding myth' originated in the liberal tradition, which in countries such as the United States gave birth to a form of 'civic religion' with a sacralised constitution as its source and centre. $^{42}$

Whether (post)Sarmatism could in any way be adapted to the role of a building material supplier for such a myth would depend on the ability of the native civic culture to de-essentialise traditionally understood Polishness $^{43}$ in favour of the essentialisation of citizenship in the modern sense. This, in turn, would require a consistent and reasonable loosening of the rigours of the community paradigm, based on which the recontextualisation and reinterpretation of Polish self-ideas, fears and

40 D. Gawin, Granice demokracji liberalnej, Kraków: Ośrodek Myśli Politycznej, 2007, p. 31.

41 Ibidem, p. 32.

42 Ibidem.

43 I am not inclined to identify traditionally understood Polishness with the Romantic or Catholic-Romantic paradigm, although this aspect appears to be undeniably important. In the light of these considerations, the basic frame of reference is (post)modernity, towards which Polishness is situated as a cultural capital with a still unassessed volume of content/value. 
hopes have been made after 1944; a paradigm shaped to a large extent by resentments, prejudices and one-sidedly conceptualised and then equally unilaterally implemented modernisation.

Originally, Sarmatism was, as we often forget, a construct unifying the interests of a multi-ethnic class structure, and in this respect, it is rich - paradoxically in the light of its stereotypical images - with symbolic content suitable for making codes regulating the issue of cultural and ethnic borderline (familiar-alien) more flexible. In this context, it is worth quoting the following excerpt from the characteristics of the nobility's mentality:

After all, due to the decentralised structure of the former Polish Republic, public life was determined by regional councils rather than the sejm in Warsaw; and thus, for a large part of the nobility, the institutions of state self-government and state privileges - the famous 'golden liberty' - were more important than the name of the state, its coat of arms and the ruling dynasty. The person of the monarch was not (unlike in absolute dynastic monarchies) considered a symbol of the state and sovereignty. The nobility's loyalty to the king was never absolute, but depended on whether the ruler observed their privileges. This 'contractual' attitude of the nobility to the monarch could be conducive to insurgent attitudes (in the tradition of the old confederations). It could also facilitate the acceptance of the new order as long as there was a shadow of hope that the new ruler would respect nobles' freedoms. The mere fact of the monarch's cultural and linguistic alienation was not an obstacle.... There was therefore nothing morally ambiguous in the fact that the Warsaw elite hoped for the Polish cause to be taken up by the Prussian king Frederick William III on the occasion of his visit to Warsaw in 1802. Tadeusz Czacki, soon the founder of the Volhynian Gymnasium in Krzemieniec, expressed the hope that the Poles would be able to explain to the Prussian king that, as a result of the partitions, he was 'the ruler of a great state, that he had ceased to be the Margrave of Brandenburg', and that the Prussian monarchy was the monarchy of Polish countries in which Germans were only officials. ${ }^{44}$

This passage can be perceived, depending on the attitude, as a record of some social aberration or as an excellent example of couleur locale. However, it can also be read as a passage that enriches the image of a specific form of civic culture. The semantics of the image would be

44 M. Janowski, Narodziny inteligencji 1750-1831, Warszawa: Instytut Historii PAN, Wydawnictwo Neriton, 2008, pp. 112-113. 
largely incomprehensible if we did not supplement it by default with the threads absent from it: moral, political, economic and so on. Of course, the distance between a stereotype and a historian's vision can be confusingly large. The discrepancies between the Sarmatism emerging from the historical discourse and its culturalist or colloquial reception are sometimes significant and make people aware of the extent of the losses suffered by the native identity discourse, when it ignores the existential dimension of the history of this formation, which deeply anchors it in the complex realities of a different time and a differently culturally and politically configured space. ${ }^{45}$

In this way, we come indirectly to another obstacle on the way to a (post)modern revision of (post)Sarmatism, which is worth mentioning at the end. The drawbacks of the hitherto attempts to revise or rediscover Sarmatism on the level of identity are the aforementioned ahistoricality and something that can be described as an excess of figurativeness. The point is that it does not make much sense to separate Sarmatism from its natural historical context in order to use it for today's purposes without maintaining even the standard respect for its historical complexity, and - on the other hand - without a certain amount of self-ironic distance, which, in liberal culture, should accompany every attempt to adapt content originating from a different cultural perspective. There must be a certain balance in attempts to fuse history with the present time. Otherwise, Sarmatism will remain a fossil into which we will try, in vain, to infuse the spirit of present needs and expectations; the result of such revival will be at best a kind of idolatry practised by a community, sanctifying its own specific form of (post)Sarmatism.

45 There are many examples of such discrepancies. Let us take the concept of tolerance, usually treated in school textbooks as one of the glorious emblems of the political system of the former Commonwealth, understood as a value per se. Meanwhile, according to Sebastian Adamkiewicz, religious tolerance in the Sarmatian Republic was understood '[...] not as an individual human right to profess one's faith, but as a political privilege resulting from civic functions. Tolerance was not meant to be an agreement between dissimilarities. Its main task was to ensure that religion would not be an obstacle to performing public functions, and thus not be a basis for questioning citizenship.' S. Adamkiewicz, Zrozumieć Polskę szlachecka, Warszawa: Histmag, 2019, p. 36, https://docer.pl/doc/xe0xve5 (accessed: November 2020). 
Although figurativeness is inherent in the nature of any discourse, it must not be forgotten that it covers to some extent, or at least cushions, the importance of the factors generating disputes (socio-economic, ethnic, geopolitical and so on). Treating Sarmatism as a product of a specific type, symbolic-narrative, moral, political or socio-economic, leads to simplifications undermining the hope for its socio-historical actualisation. A good example of such a simplification is provided by Ewa Thompson, for whom Sarmatism embodies, in the first place, a familiar 'tone of normality, a tone devoid of a sense of harm and awareness of defeat, ${ }^{46}$ which clearly distinguishes Polish consciousness of the pre-partition era from the consciousness tainted with resentment shaped by partitions and twentieth-century cataclysms (in psychological terms it would be the opposition between personalitas normalis and personalitas resentimentalis). ${ }^{47}$ However, the risk of simplification may also apply to broad, multi-factorial approaches, such as the image of the Polish-Lithuanian phantom state, drawn with great panache and intellectual freshness by Jan Sowa. According to him, Sarmatism played the role of a 'fundamental, constitutive fantasy', ${ }^{\prime 8}$ effectively hiding the lack of real Polish statehood in the seventeenth and eighteenth centuries. Sarmatism

46 E.M. Thompson, Sarmatyzm i postkolonializm, dziennik.pl, 5 November 2007, https:// wiadomosci.dziennik.pl/wydarzenia/artykuly/193060,sarmatyzm-i-postkolonializm.html (accessed: November 2020).

47 Simplification is almost elusive here, because it is based on the implicit identification of modernity with colonialism (Poland would be a victim of its specific, intra-European version), as a result of which the superior category - modernity - is replaced by a subcategory, colonialism (as one of the factors in the formation of the modern world). In this way, the latter gains unauthorised causative autonomy as an external, sinister, somewhat mysterious force of history, embodied in the politics of the three partitioning powers. The juxtaposition of healthy, pre-modern Poland and sickly, postcolonial (postmodern) Poland may therefore appear to be a cognitively 'innocent' and morally justified figure of contestation. Ewa M. Thompson's postulate to 'return' to indigenous, intact, pre-colonial Polishness is a natural result of reasoning based on figurative simplification. 'Of course, it is impossible to return to "pre-colonial" Poland, the author emphasises, 'its idyllic and angelic nature has been eaten away by the bug of colonialism and cannot be revived in the same form as it existed in the already mythologised past. The cult of political martyrdom and ugliness separates the Polish literature of the latest centuries from the earlier one and makes understanding Sarmatism difficult. One can come back to it, but it must be stylised, digested and transformed into something new.' Ibidem. 
understood in this way becomes a kind of psychotherapeutic arrangement, not a tool of evolutionary adaptation. Yet, in fact, it was both.

The consolidation of civic culture would undoubtedly be one of the forms of compensation for 'modernising deficits'. It can, of course, be assumed that such consolidation takes place somewhat automatically in connection with the new, post-1989 wave of modernisation that has swept through the Polish territories. However, it would be about increasing the share of factors conducive to its more conscious 'culturalisation', for example, by expanding its discursive background, which could favour its orientation towards a more consistent implementation of certain axiological and praxeological assumptions (in line with the spirit of democratic-liberal thinking about the state and community) and reducing the mechanism of reactivity, still very clearly present in it. Each interpretative community - and a clear example of one is a civil community - bases its claims to subjectivity and the rightness of its own reasons on a specific textual canon. It is no different with liberal communities. The stronger the awareness of the relationship with one's own canon understood in a liberal way, that is, with one's own historical contingency, the greater the chance of developing a culture of inclusiveness at the level of civic culture, replacing the exclusivist practices dominant in pre-liberal traditions (particularistic, centric, non-civic bodies striving to exclusively act on behalf of a community). In the light of this approach, recognising historical Sarmatism as the only Polish protoliberal tradition of pre-modern times should encourage a search for its later role not only in the sphere of resentment and nostalgia. The discontinuity and 'declassification' of Sarmatism - the two factors of the (post)Sarmatian fate resulting from the fall of the First Polish Republic - make it necessary to include (post) Sarmatism in the debate in the sphere of collective overworking of victories, hopes, defeats and deficits caused by modernity by Poles.

Another face of the same process would be a dialectical instead of a centric (for example, ethnocentric, romantic-patriotic and so $\mathrm{on}^{49}$ )

49 Here, centricity means, first of all, focusing attention on one dimension of collective activity and collective axiology, such as the pursuit of independence. 
insight into the mechanisms shaping Polish modernisation (nineteenth-twenty-first centuries). It could be conducive to launching codes unlocking the native identity discourse and opening it to liberalisation. In this case, it would mean greater negotiating freedom in terms of developing a discursive consensus with regard to important community issues, such as the desired formula of modernity or the hierarchy of values related to what is broadly understood as community tradition. Thus, it would also indirectly promote the recontextualisation of (post)Sarmatism, currently frozen in the Old Polish stereotype, trivialised by popular culture, compressed by the right-conservative discourse and devoid of content based on the liberal identity discourse. It cannot be denied that the postulate of 'liberalisation' of the Sarmatian canon - primarily its symbolic-narrative layer - does not correspond to the above-mentioned tendencies occurring in the sphere of popular culture, in which Sarmatism is primarily an expression of anti-modern and anti-modernist nostalgia. It also seems, however, that this form of revival of Sarmatism, developing in its own way the romantic and Sienkiewicz's national imaginary (sometimes polemical in relation to these patterns, as is the case in Jacek Komuda's works), can play a useful role in relation to the said postulate. Namely, it reveals the difficulties that must inevitably arise in connection with attempts to canonise the constructivist retro-utopian order based on at least two pillars clearly contradicting the axiology popular today: (a) exploitation and violence directed at peasants and, in part, townspeople, masked by the ideology of the noble nation; (b) phantasmal compensation for the evident shortcomings and contradictions characterising both the political system and social practices of pre-partition Poland (the weakness of the central power, the illusory nature of the foundations of economic power, the systematic degradation of the First Polish Republic's position on the international arena, class antagonisms and so on). These difficulties are, to a certain extent, reduced by the value of intertextuality, conventional metaphoricality. It is no coincidence that the most vivid reconfigurations of Sarmatian themes are now located in the epistemologically safe and ethically neutral sphere of historical fantasy, artistic utopia, ludic virtuality and social pastiche. However, probably imperceptibly for the apologists of the Sarmatian legend, and suggestively for its deconstructors, the inability 
to revive 'authentic' Sarmatism within the official cultural order manifests itself in the hypertrophy of language and the abuse of the cognitive norm. However, what might seem an irremovable weakness of (post)Sarmatism from the orthodox point of view, for the user of liberal dictionaries it may be an incentive for creative, semantic-symbolic adaptations going beyond the norm of the apologetics or rejection involved in stereotyping.

The discussion of the geopolitical thread, however, is not the subject of these considerations. However, it should be noted that its presence in the culturalist debate on Polish identity ${ }^{50}$ would not only make this debate real, but also broaden the perspective of viewing (post)Sarmatism itself as a project resonating with the sphere of non-discursive - including geopolitical - conditions. After all, at a given stage of its history, historical Sarmatism was the culmination of isolationist tendencies, a synonym of parochial quietism, but at the same time it was also the ideology of a state pursuing specific interests in the sphere of international politics and showing a certain awareness of its position in the world. ${ }^{51}$ Reluctance to or even fear of inclusion of geopolitics with its Darwinian-deterministic entourage in the identity debate, perceptible in the demo-liberal

50 For several years, this thread has been present mainly in political journalism.

51 Contemporary geopolitical thought, which seems to be experiencing a kind of renaissance in some right-wing circles, as well as in the more and more numerous analytical centres in Poland, corresponds in many points with the conviction contained in the world-systems theory (including Immanuel Wallerstein, Ferdynand Braudel) about the essential durability (secularity) of socio-economic structures that determine the status of individual countries/ regions. From this epistemological perspective, the disintegration of the Cold War system would foster the rebirth of international ties and dependencies formed at the beginning of the formation of the capitalist world-economy system (sixteenth century), in which the former Republic appears as a core area between Eastern Europe and Western Europe, mostly included in the colonial system that was being created at that time. 'From the end of the Middle Ages, between the eleventh and fifteenth centuries, two European axes of geopolitical power were formed: France in Western Europe and Poland in the east of the continent as a strong core power area around which others circulate and integrate, accepting the position and status of the Polish Republic as a central power between maritime Europe and continental Eastern Europe.' J. Bartosiak, Rzeczpospolita między ladem a morzem. O wojnie i pokoju, Warszawa: Wydawnictwo Zona Zero, 2018, p. 542. In this context, reconstructed in its political and ideological functions, as an emanation of a certain economic and geopolitical 'base', Sarmatism could turn out to be an important discursive factor from a broader reflective perspective, encompassing the entirety of Polish modern and contemporary history. 
environment and, on the other hand, the megalomania, not free from resentment, of some representatives of the neo-Sarmatian niche are two aspects of the same disease: unworked relations with modernity. This is a disease that results, inter alia, in deficiencies in the ability to conduct 'multi-factor' deliberations on complex, taboo or latent social issues and to establish real, multi-context conditions for social debates.

(Post)Sarmatism could play a visible role in strengthening Polish civic culture. The liberalisation of the language of the identity discourse and the transfer of the essential categories of this discourse to a new, civic, plane are the conditions for this strengthening, which - however difficult - seems feasible.

\section{Bibliography}

Adamkiewicz S., Zrozumieć Polskę szlachecka, Warszawa: Histmag, 2019, https://docer.pl/doc/xe0xve5.

Baczewski S., Szlachectwo. Studium z dziejów idei w piśmiennictwie polskim. Druga połowa XVI wieku - XVII wiek, Lublin: Wydawnictwo Uniwersytetu Marii Curie-Skłodowskiej, 2015.

Bakuła B., 'Kolonialne i postkolonialne aspekty polskiego dyskursu kresoznawczego (zarys problematyki)', Teksty Drugie, 2006, No. 6.

Bartosiak J., Rzeczpospolita między ladem a morzem. O wojnie i pokoju, Warszawa: Wydawnictwo Zona Zero, 2018.

Bohuszewicz P., Hermeneutyki sarmatyzmu, in: M. Lutomierski (ed.), Tradycje szlacheckie we wspótczesnej kulturze polskiej. Przybliżenia i perspektywy badawcze, Toruń: Polskie Towarzystwo Ludoznawcze, Oddział w Toruniu, 2014.

Bohuszewicz P., Pożytki z prawicowego neosarmatyzmu. (Nie-prawicowa) obrona Krzysztofa Koehlera, in: P. Biliński (ed.), Przeszłość we wspótczesnej narracji kulturowej. Studia i szkice kulturoznawcze, vol. 1, Kraków: Wydawnictwo Uniwersytetu Jagiellońskiego, 2011.

Bourdieu P., Distinction: A Social Critique of the Judgement of Taste, Cambridge, MA: Harvard University Press, 1984.

Brzeziecki A., Imperialne złudzenia Polski, https://www.reddit.com/r/Polska/ comments/6cnj0j/imperialne_z\%C5\%82udzenia_polski/.

Czapliński P., 'Plebejski, populistyczny, posthistoryczny. Formy polityczności sarmatyzmu masowego', Teksty Drugie, 2015, No. 1. 
Fukuyama F., The End of History and the Last Man, New York: The Free Press, 1992.

Gawin D., Granice demokracji liberalnej, Kraków: Ośrodek Myśli Politycznej, 2007.

Gawin D., Przekleństwo 1709 roku. Czy Polacy moga wybić się na podmiotowość?, http://www.omp.org.pl/stareomp/index2498.html?module=subjects\&fun$\mathrm{c}=$ viewpage\&pageid $=772$.

Gdyby sarmatyzm nie istniat, Michaśka sama by go wymyślita, Jakub Majmurek's interview with Przemysław Czapliński, https://krytykapolityczna.pl/ kultura/historia/czaplinski-gdyby-sarmatyzm-nie-istnial-michaska-sama -by-go-wymyslila/.

Giddens A., Beyond Left and Right: The Future of Radical Politics, Cambridge: Polity Press, 1994.

Grala H., 'Kolonializm alla polacca', Polski Przeglad Dyplomatyczny, 2017, No. 4. Janowski M., Narodziny inteligencji 1750-1831, Warszawa: Instytut Historii PAN, Wydawnictwo Neriton, 2008.

Jedlicki J., Jakiej cywilizacji Polacy potrzebuja, Warszawa: Wydawnictwo WAB; Wydawnictwo CiS, 2002.

Komuda J., 'Nobile verbum', Nowa Fantastyka, 2003, No. 8.

Kowalski J., Niezbędnik Sarmaty. Dumy, pieśni, polonezy, poprzedzony Obrona i Uświetnieniem Sarmacji Obojej, Poznań: Fundacja św. Benedykta, 2009.

Leder A., Prześniona rewolucja. Ćwiczenie z logiki historycznej, Warszawa: Wydawnictwo Krytyki Politycznej, 2014.

Ledóchowski A., 'Potop Jerzego Hoffmana', Kino, 1974, No. 2, p. 9, available at: http://www.archiwum.kino.org.pl/pdf/1974/kino_1974_02_011.pdf.

Łotman J., 'Dwa teksty semiologiczne. O pojęciu przestrzeni geograficznej w średniowiecznych tekstach staroruskich', trans. M.R. Mayenowa, Teksty. Teoria Literatury, Krytyka, Interpretacja, 1974, No. 3.

Maciejewski J., 'Sarmatyzm jako formacja kulturowa: (geneza i główne cechy wyodrębniające)', Teksty. Teoria Literatury, Krytyka, Interpretacja, 1974, No. 4.

Mętrak K., 'Potop zwycięski', Kultura, 1974, No. 36.

Mochocki M., 'Sarmackie dziedzictwo kulturowe w grze fabularnej Dzikie Pola', Homo Ludens, 2011, No. 1/3.

Monitor Warszawski, 1765, No. 30, https://www.dbc.wroc.pl/dlibra/publication/4638/edition/4474/content.

Nawarecki A., Sarmatyzm [entry], in: J. Bachórz, A. Kowalczykowa (eds.), Stownik literatury polskiej XIX wieku, Wrocław - Warszawa - Kraków: Zakład Narodowy im. Ossolińskich, 2002.

Niedźwiedź J., 'Sarmatyzm, czyli tradycja wynaleziona', Teksty Drugie, 2015, No. 1. 
Oczkowska K., Popsarmackość. Wielcy sarmaci tego kraju / Wielkie sarmatki tego kraju w BWA Tarnów, https://magazynszum.pl/popsarmackosc-wielcy-sarmaci-tego-kraju-wielkie-sarmatki-tego-kraju-w-bwa-tarnow/.

Parkitny M., Nowoczesność oświecenia. Studia o literaturze i kulturze polskiej drugiej połowy XVIII wieku, Poznań: Wydawnictwo Naukowe Uniwersytetu Adama Mickiewicza, 2018.

Scheler M., Teoria światopogladów, socjologia i ksztattowanie światopogladu, in: M. Scheler, Pisma $z$ antropologii filozoficznej $i$ teorii wiedzy, trans. S. Czerniak, A. Węgrzecki, Warszawa: Państwowe Wydawnictwo Naukowe, 1987.

Sowa J., Fantomowe ciało króla. Peryferyjne zmagania $z$ nowoczesna forma, Kraków: Universitas, 2012.

Szleszyński B., Rudkowska M. (eds.), Sienkiewicz ponowoczesny, Warszawa: Instytut Badań Literackich PAN, 2019, available at: http://nplp.pl/wp-content/uploads/2015/05/Sienkiewicz_Ponowoczesny.pdf.

Tazbir J., 'Sarmatyzm a barok', Kwartalnik Historyczny, 1969, No. 4.

Thompson E.M., Sarmatyzm i postkolonializm, 5 November 2007, dziennik.pl, https://wiadomosci.dziennik.pl/wydarzenia/artykuly/193060,sarmatyzmi-postkolonializm.html.

Toeplitz K.T., 'Potop, czyli o rzetelności', Miesięcznik Literacki, 1974, No. 11.

Urbańska M.A., Pochwała sarmatyzmu, https://www.tygodnikpowszechny.pl/ pochwala-sarmatyzmu-145412.

Vattimo G., Postnowoczesność i kres historii, trans. B. Stelmaszczyk, in: R. Nycz (ed.), Postmodernizm. Antologia przekładów, Kraków: Wydawnictwo Baran i Suszczyński, 1996.

Wierzbicki A., Spory o polska duszę. Z zagadnień charakterologii narodowej w historiografii polskiej XIX i XX wieku, Warszawa: Muzeum Historii Polski, Collegium Civitas, Wydawnictwo Trio, 2010.

Zarycki T., Wybrane kategorie analizy dyskursu w badaniu tożsamości peryferyjnej, in: A. Horolets (ed.), Analiza dyskursu $i$ dla socjologii, Toruń: Wydawnictwo Adam Marszałek, 2008.

Zarycki T., 'Recenzja książki Jana Sowy, „Fantomowe ciało króla”. Peryferyjne zmagania z nowoczesną formą,' Stan Rzeczy, 2012, No. 1.

Zeidler-Janiszewska A., O pożytkach politycznego kaskaderstwa. Szkic do portretu Odo Marquarda, in: O. Marquard, Rozstanie z filozofia pierwszych zasad, trans. K. Krzemieniowa, Warszawa: Oficyna Naukowa, 1994.

Ziemkiewicz R., 'Resztki Oświecenia', Uważam rze, 2012, No. 2, available at: http://www.old.uwazamrze.pl/artykul/805027/resztki-oswiecenia. 


\section{Problematic (Post)Sarmatism: \\ On the Possibility of Adapting Sarmatian Heritage in a Demo-liberal Culture}

The article shows (post)Sarmatism as an element of the Polish identity discourse in its community dimension, which mainly takes account of its civilisation and cultural aspect, defined by relations with (post)modernity. Although this discourse includes (post)Sarmatism in reflection on the key determinants of collective identity, such as community, Polishness and so on, it generally does so in a simplified manner, not free from prejudices and excessive bias. Liberal thought, which should have the greatest share in shaping the sphere of self-ideas of (post)modern society, shows a clear reluctance towards Sarmatian heritage, which is hardly surprising given its Enlightenment origin. However, one should understand the reasons for this reluctance, taking into account its stricter context, which is determined by the mechanism of programming Polish cultural projects in essentialist codes. Meanwhile, according to the author, the 'postmortem' history of Sarmatism (nineteenth-twenty-first centuries) is part of the pan-European struggle of Tradition and modernity. When set on this plane, (post)Sarmatism can be considered in terms of lack (discontinuation of a specific tradition) and compensation (attempts to work through modernising deficits). The Sarmatian heritage, torn out of the vicious circle of stereotypes, myths and silences, should now be included in the debate on the foundations of Polish civic culture, because it belongs to the contingent (in the liberal sense) history of the Polish habitus, and it is also characterised by the syndrome of un-working (not being discussed in contexts important from the point of view of the struggle of Polish consciousness with what is broadly understood as modernity). It also needs to be made real by being located in the circle of geopolitical discourse. The perspective of the recontextualisation of Sarmatism, which neo-Sarmatism with its essentialist-nostalgic poetics has created in contemporary identity discourse and postcolonial thought with its binary schemas, seems insufficient.

\section{Keywords:}

Poland, SARMATism, Tradition, DEMO-Liberal CULTURE. 